\title{
CYTOTOXIC EFFECTS OF SELECTED GOLD(III) COMPLEXES ON THE MURINE BCL-1 B LINEAGE LEUKAEMIA CELL LINE
}

\author{
Vladislav Volarevic ${ }^{1}$, Marija Milovanovic ${ }^{1}$, Ana Djekovic ${ }^{2}$, Živadin D. Bugarcic ${ }^{2}$ and Nebojsa Arsenijevic \\ ${ }^{1}$ Centre for Molecular Medicine and Stem Cell Research, Faculty of Medicine, University of Kragujevac \\ ${ }^{2}$ Faculty of Science, Department of Chemistry, R. Domanovica 12, P. O. Box 60, 34000 Kragujevac, Serbia
}

\section{CITOTOKSIČNI EFEKTI IZABRANIH KOMPLEKSA TROVALENTNOG ZLATA NA ĆELIJSKU LINIJU MURINE BCL-1 B LEUKEMIJE

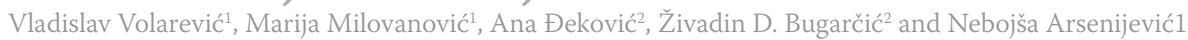 ${ }^{1}$ Centar za molekularnu medicinu I istrazivanje maticnih celija, Fakultet medicinskih nauka, Univerzitet u Kragujevcu, Kragujevac, Srbija ${ }^{2}$ Fakultet inzenjerskih nauka, Odsek za Hamiju, Radoja Domanovica 12, Kragujevac, Srbija}

\section{ABSTRACT}

In recent years, gold(III) complexes have attracted great interest because of their cytotoxicity to cancer cells.

We investigated the cytotoxic effects of three newly synthesised gold(III) complexes, $\left[\mathrm{Au}(\mathrm{en}) \mathrm{Cl}_{2}\right]^{+}$(dichloride (ethylendiamine) aurate(III)-ion), [Au(dach) $\left.\mathrm{Cl}_{2}\right]$ (dichloride (1,2diaminocyclohexane) aurate(III)-ion) and $\left[\mathrm{Au}(\text { bipy }) \mathrm{Cl}_{2}\right]^{+}$ (dichloride (2,2'-bipyridyl) aurate(III)-ion), on the murine $B C L-1$ B lineage leukaemia cell line.

The cytotoxicity of these gold(III) complexes was evaluated by cytotoxic assay (MTT test).

The results showed that all of the tested gold(III) complexes displayed a cytotoxic effect on BCL-1 cells. The concentration decrease was followed by a marked increase in BCL-1 cell viability. At a concentration of $125 \mu M$, which we suppose could be used in vivo, the $\left[\mathrm{Au}(\text { bipy }) \mathrm{Cl}_{2}\right]^{+}$complex showed the greatest cytotoxic effects among the tested gold(III) complexes and similar cytotoxicity asto the cisplatinum that we used as control. Among the tested gold(III) complexes, $\left[\mathrm{Au}(\mathrm{en}) \mathrm{Cl}_{2}\right]^{+}$ was the least cytotoxic to BCL-1 cells.

In line with the obtained results, we suggest that the $\left[\mathrm{Au} \text { (bipy) } \mathrm{Cl}_{2}\right]^{+}$complex should be tested in vivo in experimental models of B cell leukaemia.

Key words: gold(III) complexes, cytotoxicity, BCL-1 cells

\section{SAŽETAK}

Poslednjih nekoliko godina rade brojna istraživanja $u$ cilju ispitivanja citotoksičnosti jedinjenja zlata radi njihove eventualne primene $u$ onkologiji.

Mi smo ispitali citotoksičnost novosintetisanih jedinjenja zlata $[\mathrm{Au}(\mathrm{en}) \mathrm{Cl} 2]+$ (dichloride (ethylendiamine) aurate(III)ion), [Au(dach)Cl2] (dichloride (1,2-diaminocyclohexane) aurate(III)-ion) $i[\mathrm{Au}$ (bipy)Cl2]+ (dichloride (2,2'-bipyridyl) aurate(III)-ion) na BCL-1 liniji V ćelijske mišje leukemije.

Citotoksičnost je analizirana primenom MTT testa.

Naši rezultati pokazuju da sva novosintetisana jedinjenja zlata pokazuju citotoksičan efekat na BCL-1 liniji koji je dozno zavistan (smanjenje koncentracije korelira sa porastom proliferacije BCL-1 ćelija). Pri koncentraciji $125 \mu M$, za koju smatramo da treba testirati in vivo, najbolji citotoksični efekat je pokazao kompleks [Au(bipy)Cl2]+. Citotoksičnost ovog kompleksa je bila približna citotoksičnošću cisplatine koju smo koristili kao kontrolu. Među ispitivanim kompleksima najslabiju citotoksičnost na liniji V ćelijske mišje leukemije je pokazao [Au(en)Cl2]+

U skladu sa dobijenim rezultatima, smatramo da in vivo treba ispitati terapijski efekat [Au(bipy)Cl2]+ u eksperimentalnom modelu $V$ ćelijske leukemije.

Ključne reči: jedinjenja zlata, citotoksičnost, $B C L-1$ ćelije

\section{INTRODUCTION}

The success of cisplatin, carboplatin and oxaliplatin, which now play a major role in established medical treatments of cancer, has aroused great interest in the study of the cytotoxic effects of metal complexes that are isostructural to these platinum complexes [1-3].

During the last twenty years, much research has focused on gold(III) complexes, which are square-planar d8, isoelectronic

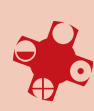

and isostructural to platinum(II) complexes. Many in vitro and in vivo studies have been conducted to investigate and precisely describe the mechanism underlying the anti-tumour effects of gold(III) complexes [3-7]. Although the results were encouraging and gold(III) compounds appeared to be very good candidates for anticancer drugs [4-7], because of their reductive potential, these complexes were not stable under physiological conditions [8]. Therefore, the selection of a suitable ligand to stabilise the complex became a foremost challenge in the de- 
sign of new gold(III) complexes with one or more multidentate ligands that enhance the stability of the complex.

We investigated and present here the cytotoxic effects of selected gold(III) complexes, $\left[\mathrm{Au}(\mathrm{en}) \mathrm{Cl}_{2}\right]^{+}$ (dichlorido(ethylendiamine)aurate(III)-ion) $\left[\mathrm{Au}(\mathrm{dach}) \mathrm{Cl}_{2}\right]$ (dichloride(1,2-diaminocyclohexane)aurate(III)-ion) and [Au(bipy)Cl $]^{+}$(dichlorido(2,2'-bipyridyl)aurate(III)-ion), on the murine $\mathrm{BCL}-1 \mathrm{~B}$ lineage leukaemia cell line .

$\mathrm{BCL}-1$ is a murine $\mathrm{B}$ lineage leukaemia cell line that was first described by Slovin and Straber [9]. BCL-1 leukaemia arose spontaneously in a 2-year-old BALB/c mouse and is easily transplanted in syngeneic recipients by injection of spleen or peripheral blood lymphocytes previously obtained from leukaemic animals [10]. BCL-1 leukaemia represents an experimental model for human chronic prolymphocytic leukaemia (PLL) [11]. The analysis of BCL-1 cell morphology showed that these cells closely resemble the prolymphocytes obtained from patients with prolymphocytic leukaemia [1011]. Further, BALB/c mice injected with BCL-1 cells develop enlarged spleens diffusely infiltrated by BCL1-prolymphocytes [10-11]. In accordance with massive splenomegaly, the murine BLC-1 leukaemia is characterised by leukocytosis (white blood cell counts $>10^{8} / \mathrm{ml}$ ), hepatomegaly and little or no lymphadenopathy [11].

This study could shed elucidate the in vitro anti-cancer properties of selected gold(III) complexes and indicate the value of investigating some of these newly synthesised gold(III) complexes in future studies.

\section{MATERIALS AND METHODS}

\section{Chemicals and ligands}

The ligands 2,2'-bipyridyl (bipy) and (1R,2R)-1,2diaminocyclohexane (dach) were obtained from Acros Organics, while the ligand ethylenediamine (en) was obtained from Sigma-Aldrich (Munich, Germany). The starting potassium tetrachloridoaurate(III) complex, $\mathrm{K}\left[\mathrm{AuCl}_{4}\right]$, was purchased from $\mathrm{ABCR} \mathrm{GmbH} \& \mathrm{Co}$ (Karlsruhe, Germany), while cisplatin (cisdiamminedichloroplatinum(II), cis- $\left.\left[\mathrm{Pt}\left(\mathrm{NH}_{3}\right)_{2} \mathrm{Cl}_{2}\right]\right)$ was purchased from Sigma-Aldrich. All chemicals were of the highest purity commercially available and were used without further purification.

For the cytotoxicity determination, further chemicals were used, including foetal bovine serum (FBS), growth medium RPMI 1640, penicillin G, streptomycin, (3-(4,5)dimethylthiazol-2-yl)-2,5-diphenyl-tetrazolium-bromide (MTT), phosphate buffered saline (PBS), dimethylsulfoxide (DMSO), trypan blue stain (all from Sigma Chemicals, Germany) and Haemaccel (Theraselect Gmbh, Germany). The assays were performed in 96-well plates (Sarstedt, Germany).

\section{Synthesis of the complexes}

The complexes $\left[\mathrm{Au}(\mathrm{en}) \mathrm{Cl}_{2}\right] \mathrm{Cl}$ and $\left[\mathrm{Au}(\right.$ bipy $\left.) \mathrm{Cl}_{2}\right] \mathrm{Cl}$ were prepared according to the published procedure [1214]. The $\left[\mathrm{Au}(\mathrm{dach}) \mathrm{Cl}_{2}\right] \mathrm{Cl}$ complex was synthesised starting from $\mathrm{KAuCl}_{4}$. Salt $(0.2 \mathrm{~g}, 0.5 \mathrm{mmol})$ was dissolved in a small amount of water and was added to the solution obtained by dissolving (1R,2R)-1,2-diaminocyclohexane $(0.057 \mathrm{~g}, 0.5 \mathrm{mmol})$ in a mixture of $\mathrm{MeOH} / \mathrm{H}_{2} \mathrm{O}(1: 1, \mathrm{v} / \mathrm{v})$. The reaction was stirred for $5 \mathrm{~h}$ at room temperature. The yellow solution obtained was left to evaporate in darkness. After a few days, the yellow crystals that had formed were filtered, washed with cold water and dried. Found: $\mathrm{H}, 4.91$; C, 13.66; N, 2.84; Calc. for $\mathrm{AuC}_{6} \mathrm{H}_{14} \mathrm{~N}_{2} \mathrm{Cl}_{3}: \mathrm{H}, 5.34 ; \mathrm{C}, 13.80$; $\mathrm{N}, 2.71 \%$.

\section{Cell culture}

The BCL-1, murine B lineage leukaemia cell line, syngeneic in $\mathrm{BALB} / \mathrm{c}$ mice, was purchased from the American Type Culture Collection (ATCC) Manassas, VA, USA. The BCL-1 cells were cultured in RPMI 1640 medium with 2 $\mathrm{mM}$ L-glutamine and $0.05 \mathrm{mM}$ 2-mercaptoethanol containing 15\% FBS, $100 \mathrm{IU} / \mathrm{mL}$ penicillin $\mathrm{G}$ and $100 \mu \mathrm{g} / \mathrm{mL}$ streptomycin (Sigma-Aldrich chemical, Munich, Germany). BCL-1 cells from the third passage were used throughout these experiments.

\section{Cytotoxicity assay}

The effects of $\left[\mathrm{Au}(\mathrm{en}) \mathrm{Cl}_{2}\right]^{+}\left[\mathrm{Au}(\right.$ dach $\left.) \mathrm{Cl}_{2}\right]$ and $[\mathrm{Au}$ (bipy) $\left.\mathrm{Cl}_{2}\right]^{+}$complexes on $\mathrm{BCL}-1$ cell viability were determined using the MTT 3-(4,5-Dimethylthiazol-2-yl)-2,5-diphenyltetrazolium bromide) colorimetric test [15].

BCL-1 cells were diluted with medium to $1 \times 10^{5}$ cells/ $\mathrm{mL}$, aliquots $\left(1 \times 10^{4}\right.$ cells $\left./ 100 \mu \mathrm{L}\right)$ were placed in individual wells in 96-well plates, and $100 \mu \mathrm{L}$ of complexes diluted in medium in selected concentrations were added. Cells were treated with selected concentrations of complexes for three days. Control wells were prepared by adding culture medium. Wells containing culture medium without cells were used as blanks. The MTT solution was prepared as 5 $\mathrm{mg} / \mathrm{ml}$ in PBS just before use and filtered through a 0.22$\mu \mathrm{m}$ filter. After incubation, the cells were pelleted, and the drug-containing medium was discarded and replaced with serum-free medium containing $15 \%$ MTT solution. After an additional $4 \mathrm{~h}$ of incubation at $37^{\circ} \mathrm{C}$ in a $5 \% \mathrm{CO}_{2}$ incubator, the medium with MTT was removed, and DMSO $(150 \mu \mathrm{L})$ with glycine buffer $(20 \mu \mathrm{L})$ was added to dissolve the blue formazan crystals. The plates were shaken for $10 \mathrm{~min}$. The optical density of each well was determined at $595 \mathrm{~nm}$.

The percentage of cytotoxicity was calculated using the following formula:

$\%$ of viable cells $=(\mathrm{E}-\mathrm{B}) /(\mathrm{K}-\mathrm{B}) \times 100$

where $B$ is for the background optical density of the medium alone, $\mathrm{K}$ is for the total viability/spontaneous death of untreated target cells, and $\mathrm{E}$ is for the experimental well.

\section{STATISTICAL ANALYSES}

Where appropriate, the data were presented as means +/- SD. Statistical analyses were performed by ANOVA followed by the Bonferroni test. The level of significance was set at $\mathrm{p}<0.05$. 


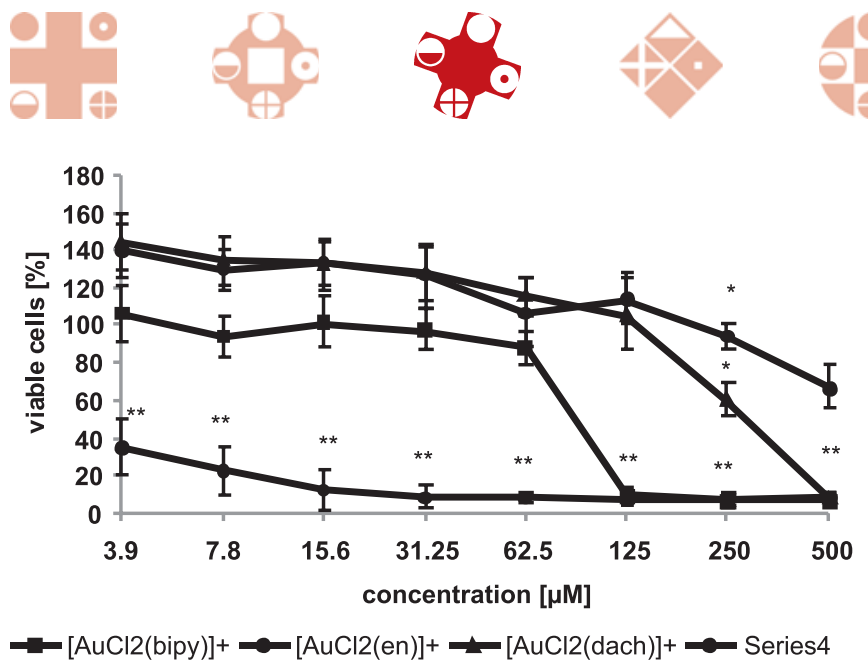

Figure 1. Toxicity of the $\left[\mathrm{Au}(\mathrm{bipy}) \mathrm{Cl}_{2}\right]^{+},\left[\mathrm{Au}(\mathrm{dach}) \mathrm{Cl}_{2}\right]^{+}$and $\left[\mathrm{Au}(\mathrm{en}) \mathrm{Cl}_{2}\right]^{+}$and cisplatin $\left[\mathrm{PtCl}_{2}\left(\mathrm{NH}_{3}\right)_{2}\right]$ complexes, using $\mathrm{BCL}-1$ cells as the target cells. BCL-1 cells were cultured with different doses of the tested complexes, ranging from 3.9 to $500 \mu \mathrm{M}$. Cell viability was determined based on the MTT assay. Each point represents the mean value of three experiments with three replicates per dose. The data are presented as mean +/- SD ("p $\left.<0.05:{ }^{* *} \mathrm{p}<0.01\right)$.

\section{RESULTS}

All three of the gold(III) complexes showed cytotoxic effects on BCL-1 cells (Figures 1 and 2).

At concentrations from $3.9 \mu \mathrm{M}$ to $125 \mu \mathrm{M}$, all of the tested complexes showed similar and low cytotoxic effects. Furthermore, BCL-1 cells that were treated with $[\mathrm{Au}(\mathrm{en})$ $\left.\mathrm{Cl}_{2}\right]^{+}$and $\left[\mathrm{Au}(\text { dach }) \mathrm{Cl}_{2}\right]^{+}$complexes (at concentrations from $3.9 \mu \mathrm{M}$ to $125 \mu \mathrm{M}$ ) managed to proliferate.

The cytotoxic effects of gold(III) complexes on BCL-1 cells differed at the concentration of $125 \mu \mathrm{M}(\mathrm{p}<0.05)$. The $\left[\mathrm{Au} \text { (bipy) } \mathrm{Cl}_{2}\right]^{+}$complex showed high cytotoxicity, killing almost $100 \%$ of the cells, while the other two tested complexes had very low cytotoxic effects. Interestingly, BCL-1 cells proliferated after treatment with $\left[\mathrm{Au}(\mathrm{en}) \mathrm{Cl}_{2}\right]^{+}$and $\left[\mathrm{Au}(\text { dach }) \mathrm{Cl}_{2}\right]^{+}$complexes (at a concentration of $125 \mu \mathrm{M}$ ).

The cytotoxicity of $\left[\mathrm{Au}(\mathrm{en}) \mathrm{Cl}_{2}\right]^{+}$and $\left[\mathrm{Au}(\text { dach }) \mathrm{Cl}_{2}\right]^{+}$ complexes to BCL-1 cells differed significantly at $250 \mu \mathrm{M}$ $(\mathrm{p}<0.05)$. At this concentration, both complexes showed cytotoxic effects on BCL-1 cells. The percentage of viable BCL-1 cells was about $60 \%$ after treatment with $[\mathrm{Au}(\mathrm{dach})$ $\left.\mathrm{Cl}_{2}\right]^{+}$and about $94 \%$ after treatment with $\left[\mathrm{Au}(\mathrm{en}) \mathrm{Cl}_{2}\right]^{+}$, suggesting that among the tested gold(III) complexes, [ $\mathrm{Au}(\mathrm{en})$ $\left.\mathrm{Cl}_{2}\right]^{+}$was the least cytotoxic to BCL-1 cells. On the contrary, approximately $5 \%$ of BCL-1 cells were viable after treatment with $\left[\mathrm{Au}(\text { bipy }) \mathrm{Cl}_{2}\right]^{+}$, confirming the high cytotoxic potential of $\left[\mathrm{Au} \text { (bipy) } \mathrm{Cl}_{2}\right]^{+}$on BCL-1 cells.

These results were confirmed at the concentration of $500 \mu \mathrm{M}$. [Au(bipy) $\left.\mathrm{Cl}_{2}\right]^{+}$and $\left[\mathrm{Au}(\text { dach }) \mathrm{Cl}_{2}\right]^{+}$complexes showed high cytotoxicity (almost $100 \%$ of BCL-1 cells were killed), while the percentage of viable BCL-1 cells after treatment with $\left[\mathrm{Au}(\mathrm{en}) \mathrm{Cl}_{2}\right]^{+}$was still high (approximately 67\%).

It is interesting to note that the cisplatin complex showed high and dose-independent cytotoxicity on BCL-1 cells (Figures 2 and 3).

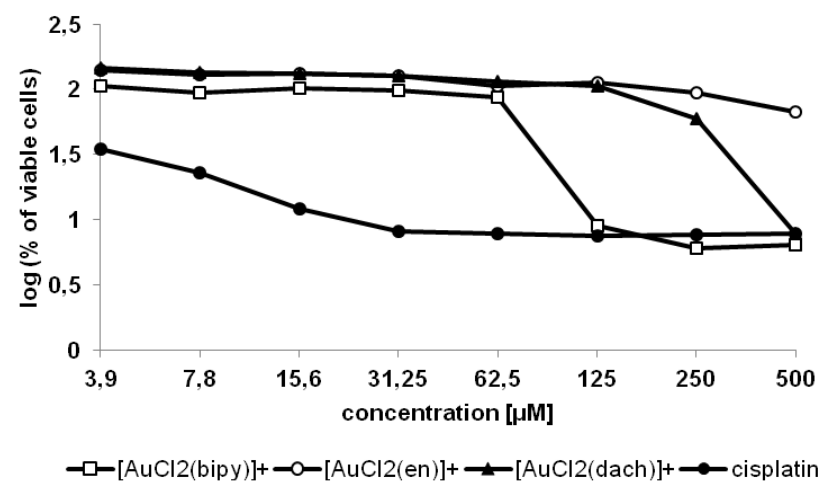

Figure 2. Semi-logarithmic plot of cytotoxic effects of $\left[\mathrm{Au}(\mathrm{bipy}) \mathrm{Cl}_{2}\right]^{+}$, $\left[\mathrm{Au}(\text { dach }) \mathrm{Cl}_{2}\right]^{+}$and $\left[\mathrm{Au}(\mathrm{en}) \mathrm{Cl}_{2}\right]^{+}$and cisplatin $[\mathrm{PtCl} 2(\mathrm{NH} 3) 2]$ complex on BCL-1 cells.

Each point represents a mean value of three experiments with three replicates per dose.

\section{DISCUSSION}

We, here, for the first time, report the cytotoxic effects of newly synthesised $\left[\mathrm{Au}(\text { bipy }) \mathrm{Cl}_{2}\right]^{+},\left[\mathrm{Au}(\mathrm{dach}) \mathrm{Cl}_{2}\right]^{+}$and $\left[\mathrm{Au}(\mathrm{en}) \mathrm{Cl}_{2}\right]^{+}$gold(III) complexes on the BCL-1 murine $\mathrm{B}$ lineage leukaemia cell line. Our results showed that all of the tested gold(III) complexes displayed cytotoxic effects on BCL-1 cells (Figures 2 and 3). The concentration decrease was followed by a marked increase in BCL-1 cell viability (Figure 3).

At the concentration of $125 \mu \mathrm{M}$, which we suppose could be used in vivo, the $\left[\mathrm{Au}(\text { bipy }) \mathrm{Cl}_{2}\right]^{+}$complex showed the greatest cytotoxic effects among the tested gold(III) complexes and similar cytotoxicity compared to the cisplatinum control. At $125 \mu \mathrm{M}$, only 24 hours after treatment with $\left[\mathrm{Au}(\text { bipy }) \mathrm{Cl}_{2}\right]^{+}$, almost all of the BCL-1 cells were dead (Figure 3).

Recently, described activation parameters for kinetic reactions important for the synthesis of the tested complexes [16] suggest that an associative substitution mechanism is responsible for the different cytotoxic effects of [Au(bipy) $\left.\mathrm{Cl}_{2}\right]^{+},\left[\mathrm{Au}(\text { dach }) \mathrm{Cl}_{2}\right]^{+}$and $\left[\mathrm{Au}(\mathrm{en}) \mathrm{Cl}_{2}\right]^{+}$gold(III) complexes. As previously described [14, 16-17], the first reaction step occurs via nucleophilic attack of the N7 donor atom of the purine base in 5'-GMP, resulting in the formation of a product by the departure of one chloride ion. The second step includes the substitution of another chloride ion from the starting complex, when 1:2 complexes are formed. Both the first and second steps of the substitution of the $\left[\mathrm{Au} \text { (bipy) } \mathrm{Cl}_{2}\right]^{+}$complex are faster than those in the case of the $\left[\mathrm{Au}(\mathrm{dach}) \mathrm{Cl}_{2}\right]^{+}$and $\left[\mathrm{Au}(\mathrm{en}) \mathrm{Cl}_{2}\right]^{+}$complexes, suggesting higher efficacy of the $\left[\mathrm{Au} \text { (bipy) } \mathrm{Cl}_{2}\right]^{+}$complex.

Although the cisplatin complex shows high cytotoxicity on BCL-1 cells, it was previously reported [4] that gold(III) complexes are better tolerated in vivo because of the different anticancer mechanisms utilised by gold complexes and cisplatin. The main anticancer mechanism of the cisplatin 
complex is its interaction with DNA. The cisplatin complex forms an adduct that interferes with transcription and replication, which is followed by apoptosis of the cancer cell [18]. The interactions of cisplatin with DNA result in a PtGG intrastrand crosslink that is the critical lesion leading to cisplatin toxicity dominantly manifested by dysfunction of gastrointestinal and haematological systems [18-19]. Although the main intracellular target for gold(III) complexes and the precise mechanisms responsible for their anticancer effect are still unknown, some recently published data suggest that their mechanisms of action, such as modification of surface protein residues and inhibition of proteasome function [20], are substantially different from that of the cisplatin complexes.

In view of our results, we suggest that the $\left[\mathrm{Au}(\text { bipy }) \mathrm{Cl}_{2}\right]^{+}$ complex should be tested in vivo in experimental models of $B$ cell leukaemia.

\section{Acknowledgements}

The authors gratefully acknowledge financial support from the Faculty of Medicine at the University of Kragujevac (project JP07/10) and the Ministry of Science and Technological Development of the Republic of Serbia (project Nos. ON175069 and ON175103).

\section{REFERENCES}

1. Jung Y, Lippard SJ. Direct cellular responses to platinum-induced DNA damage. Chem Rev. 2007;107: 1387-407.

2. Jakupec MA, Galanski M, Arion VB, Hartinger CG, Keppler BK. Antitumour metal compounds: more than theme and variations. Dalton Trans. 2008;2:183-94.

3. Wang X, Guo Z. Towards the rational design of platinum(II) and gold(III) complexes as antitumour agents. Dalton Trans. 2008;12:1521-32.

4. Volarevic V, Milovanovic M, Djekovic A, Petrovic B, Arsenijevic N, Bugarcic ZD. The cytotoxic effects of some selected gold(III) complexes on 4T1 cells and their role in the prevention of breast tumor growth in BALB/c mice. J BUON. 2010;15:768-73.

5. Isab AA, Shaikh MN, Monim-ul-Mehboob M, Al-Maythalony BA, Wazeer MI, Altuwaijri S. Synthesis, characterization and anti proliferative effect of [Au(en)2] $\mathrm{Cl} 3$ and $[\mathrm{Au}(\mathrm{N}$-propyl-en)2]Cl3 on human cancer cell lines. Spectrochim Acta A Mol Biomol Spectrosc. 2011;79:1196-201.

6. Che CM, Sun RW. Therapeutic applications of gold complexes: lipophilic gold(III) cations and gold(I) complexes for anti-cancer treatment. Chem Commun (Camb). 2011;47:9554-60.
7. Marzano C, Ronconi L, Chiara F, Giron MC, Faustinelli I, Cristofori P, Trevisan A, Fregona D. Gold(III)-dithiocarbamato anticancer agents: activity, toxicology and histopathological studies in rodents. Int J Cancer. 2011;129:487-96.

8. Messori L, Abbate F, Marcon G, Orioli P, Fontani M, Mini E, Mazzei T, Carotti S, O'Connell T, Zanello P. Gold(III) complexes as potential antitumor agents: solution chemistry and cytotoxic properties of some selected gold(III) compounds. J Med Chem. 2000;43:3541-8.

9. Slavin S, Strober S. Spontaneous murine B cell leukemia. Nature 1977; 272: 624.

10. Muirhead MJ, Isakson PC, Krolick KA, Uhr JW, Vitetta ES. BCL1, a murine model of prolymphocytic leukemia. I. Effect of splenectomy on growth kinetics and organ distribution. Am J Pathol. 1981;105:295-305.

11. Muirhead MJ, Holbert JM Jr, Uhr JW, Vitetta ES. BCL1, a murine model of prolymphocytic leukemia. II. Morphology and ultrastructure. Am J Pathol. 1981; 105:306-15.

12. Djeković A, Petrović B, Bugarčić ZD, Puchta R, van Eldik R. Kinetics and mechanism of the reactions of $\mathrm{Au}(\mathrm{iii})$ complexes with some biologically relevant molecules. Dalton Trans. 2012 Feb 9. [Epub ahead of print]

13. Zhu S, Gorski W, Powell DR, Walmsley JA. Synthesis, structures, and electrochemistry of gold(III) ethylenediamine complexes and interactions with guanosine 5'monophosphate. Inorg Chem. 2006;45:2688-94.

14. Milovanović M, Djeković A, Volarević V, Petrović B, Arsenijević N, Bugarcić ZD. Ligand substitution reactions and cytotoxic properties of $[\mathrm{Au}(\mathrm{L}) \mathrm{Cl} 2](+)$ and [AuCl2(DMSO)2]+ complexes ( $\mathrm{L}=$ ethylenediamine and Smethyl-1-cysteine). J. Inorg. Biochem. 2010; 104: 944-949.

15. Mosmann T. Rapid colorimetric assay for cellular growth and survival: application to proliferation and cytotoxicity assays. J. Immunol. Meth. 1983; 65: 55-63.

16. Arsenijevic M, Milovanovic M, Volarevic V, Djekovic A, Kanjevac T, Arsenijevic N, Đukić S and Bugarčic ZD. Cytotoxicity of gold (III) complexes on A549 human lung carcinoma epithelial cell line. Med Chem 2011; 7 (in press)

17. Shounan Y, Feng X, O'Connell PJ. Apoptosis detection by annexin $\mathrm{V}$ binding: a novel method for the quantitation of cell-mediated cytotoxicity. J. Immunol. Methods. 1998; 217: 61-70.

18. Abrams MJ, Murrer BA. Metal compounds in therapy and diagnosis. Science 1993; 261: 725-730.

19. Ott I, Gust R. Non platinum metal complexes as anti-cancer drugs. Arch Pharm (Weinheim). 2007;340:117-26.

20. Ronconi L, Marzano C, Zanello P, Corsini M, Miolo G, Maccà C, Trevisan A, Fregona D. Gold(III) dithiocarbamate derivatives for the treatment of cancer: solution chemistry, DNA binding, and hemolytic properties. J Med Chem. 2006;49:1648-57. 